\title{
POTENSI EKSTRAK KULIT BUAH MANGGIS SEBAGAI INHIBITOR KOROSI BAJA KARBON DALAM LARUTAN NaCI 1\% JENUH KARBON DIOKSIDA
}

\author{
TETY SUDIARTI $^{1 *}$, NIA ANRIYANI $^{1}$, DAN ASEP SUPRIADIN $^{1}$ \\ ${ }^{1}$ Jurusan Kimia, Fakultas Sains dan Teknologi,UIN Sunan Gunung Djati Bandung, \\ Jl. A. H. Nasution No. 105 Cibiru Kota Bandung \\ *alamat email korespondensi: tety.sudiarti@uinsgd.ac.id
}

\begin{abstract}
Riwayat Naskah
Abstrak/Abstract

Riwayat Naskah :

Pemanfaatan limbah bahan alam sebagai inhibitor korosi belum banyak dilaporkan.

Diterima pada 19

Desember 2018

Diantaranya adalah kulit buah manggis (Garcinia mangostana L.) yang dalam bentuk

Diterima setelah

direvisi pada 29

Januari 2019

Diterbitkan pada 30

Januari 2019

ekstraknya mengandung senyawa golongan flavonoid, alkaloid, dan tanin. Senyawa-senyawa tersebut berpotensi memiliki aktivitas inhibisi korosi dikarenakan memiliki gugus-gugus yang dapat teradsorpsi kuat pada permukaan logam. Penelitian ini bertujuan untuk mengetahui aktivitas inhibisi ekstrak kulit buah manggis pada baja karbon dalam medium $\mathrm{NaCl} 1 \%$ yang dijenuhi gas karbondioksida. Pelarut etil asetat digunakan untuk mengekstraksi kulit buah manggis menggunakan metode maserasi. Karakterisasi yang dilakukan adalah uji fitokimia dan analisis gugus fungsi dengan FTIR. Metode Tafel digunakan untuk menentukan aktivitas

Kata Kunci: Ekstrak inhibisinya. Aktivitas inhibisi ekstrak kulit buah manggis meningkat dengan naiknya konsentrasi inhibitor. Efisiensi inhibisi optimum pada konsentrasi 40 ppm sebesar 60,37\%. kulit buah manggis; ekstrapolasi Tafel; inhibitor; korosi; Kenaikan suhu dari $25-55^{\circ} \mathrm{C}$ menyebabkan aktivitas inhibisi menurun dan mencapai efisiensi inhibisi optimum pada suhu $25^{\circ} \mathrm{C}$.

elektrolit.

Keywords: Garcinia mangostana peel extract; Tafel extrapolation; corrosion; inhibitor; electrolyte.

Garcinia mangostana peel has a chemical content that is potentially used as a corrosion inhibitor due to containing flavonoids, alkaloids and tannins that are thought to act as corrosion inhibitors. The objective of this study was to analyze the corrosion inhibitory activity of garcinia mangostana peel extract compounds on carbon steel in a saturated carbon dioxide electrolyte solution. Garcinia mangostana peel was extracted using ethyl acetate solvent by maceration method and characterized by phytochemical test and functional group analysis with FTIR. The inhibition activity of the garcinia mangostana peel extract compound was analyzed by Tafel extrapolation method with concentration and temperature variation. The media environment used is a $\mathrm{NaCl} 1 \%$ solution of saturated $\mathrm{CO}_{2}$. Efficiency of optimum inhibition at 40 ppm concentration was $60.37 \%$. The rise in temperature from $25-55^{\circ} \mathrm{C}$ caused inhibition activity to decrease and achieved optimum inhibition efficiency at $25^{\circ} \mathrm{C}$.
\end{abstract}

\section{PENDAHULUAN}

Korosi adalah berkurangnya kualitas suatu material (biasanya berupa logam atau campuran logam) sebagai akibat adanya interaksi dengan lingkungannya yang berlangsung secara berangsur-angsur yang dapat terjadi akibat interaksi secara fisika, kimia atau adanya pengaruh mahluk hidup (mikroorganisme) [1] [2]. Pada umumnya korosi pada logam disebabkan oleh proses elektrokimia yang terjadi pada permukaan logam dan atau pada antarmuka logam/larutan. Karenanya reaksi korosi merupakan reaksi heterogen yang sering kali dikendalikan oleh proses difusi.

Untuk mencegah terjadinya korosi, maka pemeliharaan dan usaha meminimalkan proses serangan korosi terhadap jaringan pipa produksi pengalir minyak di industri pertambangan untuk memaksimalkan waktu pakainya, merupakan kegiatan perawatan fasilitas produksi yang dilakukan secara kontinu dan memerlukan penggunaan inhibitor korosi. Inhibisi adalah cara yang paling umum untuk mengendalikan korosi dalam jaringan pipa produksi di lingkungan air. Inhibitor yang digunakan harus mampu mencegah dan menanggulangi korosi terlokalisasi dalam semua kasus yang mungkin terjadi.

Peraturan perundang-undangan yang ketat tentang lingkungan mengharuskan pemilihan inhibitor yang berkinerja tinggi, ramah lingkungan, serta tidak mengganggu proses produksi. Pada pekerjaan ini digunakan inhibitor senyawa organik karena mudah terdegradasi, sehingga tidak mencemari lingkungan. Sebagai inhibitor organik dipilih inhibitor yang berasal dari limbah bahan alam yaitu kulit buah manggis (Garcinia mangostana L.) yang dalam bentuk ekstraknya mengandung senyawa golongan flavonoid, alkaloid, dan tanin. Senyawa-senyawa 
tersebut berpotensi memiliki aktivitas inhibisi korosi dikarenakan memiliki gugus-gugus yang dapat teradsorpsi kuat pada permukaan logam. Penelitian ini bertujuan untuk mengetahui aktivitas inhibisi ekstrak kulit buah manggis pada baja karbon dalam medium $\mathrm{NaCl} 1 \%$ yang dijenuhi gas karbondioksida dengan metode Tafel.

\section{EKSPERIMEN}

\section{Material}

Bahan-bahan yang digunakan dalam penelitian ini adalah kulit manggis (Garcinia mangostana L.), etil asetat, etanol $96 \%$, baja karbon, larutan uji (larutan $\mathrm{NaCl} 1 \%$ yang dijenuhi gas $\mathrm{CO}_{2}$ berperan sebagai medium korosif), metanol, $\mathrm{FeCl}_{3}$, serbuk $\mathrm{Mg}, \mathrm{HCl}$, Dragenrof, akuades dan inhibitor (ekstrak Kulit manggis (Garcinia mangostana L.)).

\section{Instrumentasi}

Alat-alat yang digunakan meliputi sel elektrokimia tiga elektroda, peralatan Gamry reference 3000, dan program software Echem gamry, Fourier Transform Infra Red (FTIR) (Prestige 21 Shimadzu).

\section{Prosedur}

\section{Preparasi Kulit Buah Manggis}

Kulit buah manggis yang telah dikupas dan dipisahkan, di potong kecil dan dikeringkan, lalu dihaluskan dengan menggunakan belender sampai terbentuk serbuk dalam ukuran yang sangat halus.

\section{Ekstraksi Kulit Buah manggis}

Ditimbang $500 \mathrm{~g}$ serbuk kering kulit buah manggis dimasukkan kedalam botol kaca, kemudian ditambahkan $375 \mathrm{~mL}$ etil asetat. Maserasi dilakukan selama 3 kali 24 jam, dan setiap 24 jam ekstrak etil asetat disaring dan dimaserasi kembali. Ekstrak etil asetat kulit buah manggis yang diperoleh, diuapkan dengan menggunakan penguap putar vakum (rotary vacum evaporator) pada rentang suhu $30-400{ }^{\circ} \mathrm{C}$ sampai terbentuk ekstrak kental etil asetat.

\section{Uji Fitokimia}

Uji Fitokimia dilakukan untuk menentukan adanya senyawa-senyawa metabolit sekunder pada ekstrak kulit buah manggis seperti uji tanin menggunakan larutan $\mathrm{FeCl}_{3} 1 \%$, uji alkaloid menggunakan larutan Dragenroff dan uji flavanoid dengan menggunakan serbuk $\mathrm{Mg}$, larutan atOH : $\mathrm{HCl}$ (1:1) dan amil alkohol.

\section{Analisis Gugus Fungsi (FTIR)}

Untuk mengetahui gugus-gusus fungsi yang terdapat pada sampel ekstrak kulit buah manggis maka dilakukan analisis dengan menggunakan instrumen FTIR.

\section{Uji Inhibisi (Metode Tafel)}

Untuk mengetahui aktivitas inhibisi dari ekstrak kulit buah manggis maka dilakukan uji inhibisi korosi pada baja karbon menggunakan metode ekstrapolasi Tafel dengan variasi konsentrasi inhibitor mulai dari $8 \mathrm{ppm}$, dengan kenaikan konsentrasi berikutnya tiap $8 \mathrm{ppm}$. Selanjutnya dilakukan uji inhibisi dengan variasi suhu pada $25^{\circ} \mathrm{C}, 35^{\circ} \mathrm{C}, 45^{\circ} \mathrm{C}$ dan $55^{\circ} \mathrm{C}$ dalam larutan $\mathrm{NaCl} 1 \%$ yang dijenuhi gas $\mathrm{CO}_{2}$ yang berperan sebagai medium korosif.

\section{HASIL DAN PEMBAHASAN}

\section{Uji Fitokimia}

Uji fitokimia dilakukan setelah proses maserasi untuk mengetahui golongan senyawa yang terdapat pada ekstrak kulit buah manggis, uji fitokimia pada ekstrak kulit buah manggis fraksi etil asetat dan fraksi etanol menunjukkan hasil positif mengandung tanin, alkaloid dan flavonoid. Alkaloid memiliki basa nitrogen pada rantai sikliknya dan mengandung beragam substituen sehingga alkaloid sersifat semi polar. Tanin termasuk golongan polifenol yang terbagi menjadi dua golongan yaitu tanin terhidrolisis dan tanin terkondensasi. Hasil uji tanin berwarna hijau kehitaman menunjukkan tanin pada ekstrak kulit buah manggis merupakan tanin terkondensasi yang bersifat non polar. Flavonoid memiliki gugus terhidroksi yang tidak tersubtitusi sehingga bersifat polar. Perolehan uji fitokimia menunjukkan hasil positif flavanoid dengan terbentuknya warna kuning dan positif alkaloid dengan terbentuknya warna jingga bagi ekstrak kulit manggis fraksi etil asetat maupun etanol, akan tetapi memiliki perbedaan kepekatan warna pada hasil uji fitokimia yang dapat ditunjukkan pada Gambar 1 berikut: 


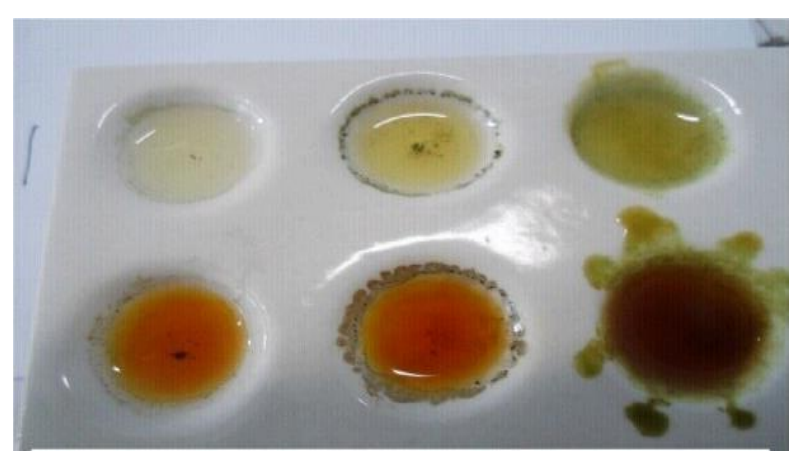

Gambar 1. Hasil uji fitokimia

Hasil uji fitokimia ini menunjukkan bahwa pelarut etil asetat memiliki kepekatan warna yang lebih tinggi dibandingkan pelarut etanol.

\section{Analisis FTIR}

Hasil analisis FTIR ditunjukkan pada Gambar 2. Gugus- gugus yang terdapat dalam ekstrak kulit buah manggis terdiri dari $\mathrm{OH}-$, Alkana C-H, Aromatik C-H, C=O. Gugus O-H (hidroksil) ditunjukkan oleh puncak serapan pada bilangan gelombang $3247 \mathrm{~cm}^{-1}$. Gugus alkana ditunjukkan oleh puncak serapan pada bilangan gelombang $1461 \mathrm{~cm}^{-1}$ yang memiliki sifat nonpolar dan hidrofobik sehingga mampu menolak air, gugus aromatik C-H (fenil) ditunjukkan oleh puncak serapan pada bilangan gelombang 1013 $\mathrm{cm}^{-1}$ yang menunjukan senyawa polifenol bersifat polar, gugus $\mathrm{C}=\mathrm{O}$ (karbonil) ditunjukkan oleh puncak serapan pada bilangan gelombang 1656 $\mathrm{cm}^{-1}$ dimana merupakan heteroatom yang menunjukkan adanya kemampuan teradsorpsi pada permukaan baja. Dari hasil spektra FTIR bahwa golongan senyawa aktif pada ekstrak kulit manggis merupakan senyawa aromatik fenolik yang berperan sebagai antioksidan dan heteroatom yang teradsorpsi di permukaan baja. Selain itu adanya gugus alkana $\mathrm{C}-\mathrm{H}$ yang bersifat non-polar dan hidrofobik sehingga menolak air pada permukaan baja. Gugus-gugus fungsi yang ditentukan dari hasil panjang gelombang IR hasil penelitian isolat murni merupakan gugus-gugus fungsi yang terdapat pada senyawa flavonoid dengan daerah spektra yang terbaca berkisar antara 3000-500 $\mathrm{cm}^{-1}$ dan termasuk dalam IR tengah. Sehingga isolat murni yang didapatkan pada hasil penelitian dapat diduga merupakan senyawa flavonoid.

Dugaan senyawa tanin juga diperkuat dengan adanya serapan pada bilangan gelombang $1461 \mathrm{~cm}^{-1}$ dengan intensitas lemah dan bentuk pita tajam pada kedua isolat tersebut yang menunjukkan adanya $\mathrm{C}=\mathrm{C}$ aromatik Spektrum inframerah (Gambar 2) menunjukkan bahwa senyawa mempunyai gugus fungsi karakteristik yang sama yaitu gugus $-\mathrm{O}-\mathrm{H}, \mathrm{C}-\mathrm{H}$ alifatik, $\mathrm{C}=\mathrm{O}$ ester, $\mathrm{C}=\mathrm{C}$ aromatik, $\mathrm{C}-\mathrm{O}-\mathrm{H}$, dan $\mathrm{C}-\mathrm{O}-\mathrm{C}$ eter.



Gambar 2. Hasil Spektrum FTIR

Puncak-puncak tersebut merupakan puncak spesifik dari senyawa tanin khususnya tanin terhidrolisis, sehingga memperkuat dugaan bahwa senyawa merupakan tanin terhidrolisis. Hasil analisis menggunakan spektrofotometer FTIR memberikan bilangan gelombang sebesar 3424 $\mathrm{cm}^{-1}$ (vibrasi ulur $\mathrm{OH}$ ), $1613 \mathrm{~cm}^{-1}$ (vibrasi ulur $\mathrm{C}=\mathrm{N}$ ) yang diperkuat dengan serapan $1078 \mathrm{~cm}^{-1}$ (vibrasi tekuk C-N yang simetri dengan vibrasi ulur C-O), $2923 \mathrm{~cm}^{-1}$ dan $2933 \mathrm{~cm}^{-1}$ (vibrasi ulur C-H alifatik), $1461 \mathrm{~cm}^{-1}$ dan $1374 \mathrm{~cm}^{-1}$ (gugus C$\mathrm{H}), 1737 \mathrm{~cm}^{-1}$ (vibrasi ulur $\mathrm{C}=\mathrm{O}$ ), $1656 \mathrm{~cm}^{-1}$ (vibrasi ulur $\mathrm{C}=\mathrm{C}$ terkonyugasi), $631 \mathrm{~cm}^{-1}(\mathrm{C}-\mathrm{H}$ alifatik keluar bidang), dari hasil FTIR tersebut dapat diketahui bahwa terdapat suatu senyawa alkaloid yang terkandung dalam ekstrak kulit buah manggis.

\section{Analisis Hasil Uji Inhibisi (metode Tafel)}

\section{Jenis Inhibitor}

Melalui metode Tafel, dapat diperoleh beberapa parameter korosi tetapi yang diambil pada penelitian ini hanya laju korosinya. Nilai laju korosi sebanding dengan nilai $I_{\text {corr }}$ yang diperoleh dari ekstrapolasi grafik pengukuran rapat arus katoda dan anoda terhadap potensial.

Dapat dianalisis dari aluran Tafel pada Gambar 3, dengan adanya inhibitor kerapatan arus korosi, $I_{\text {corr }}$ menurun dibandingkan dengan larutan blanko. Karena besarnya kerapatan arus berbanding lurus dengan laju korosi maka semakin besar penurunan kerapatan arus $\left(\Delta I_{\text {corr }}\right)$ maka laju korosi semakin kecil dan efektifitas inhibitor tersebut semakin meningkat [3]. Dari aluran Tafel tersebut menunjukkan bahwa senyawa inhibitor fraksi semi polar, memperlihatkan daya inhibisi korosi tertinggi pada konsentrasi 40 ppm. 


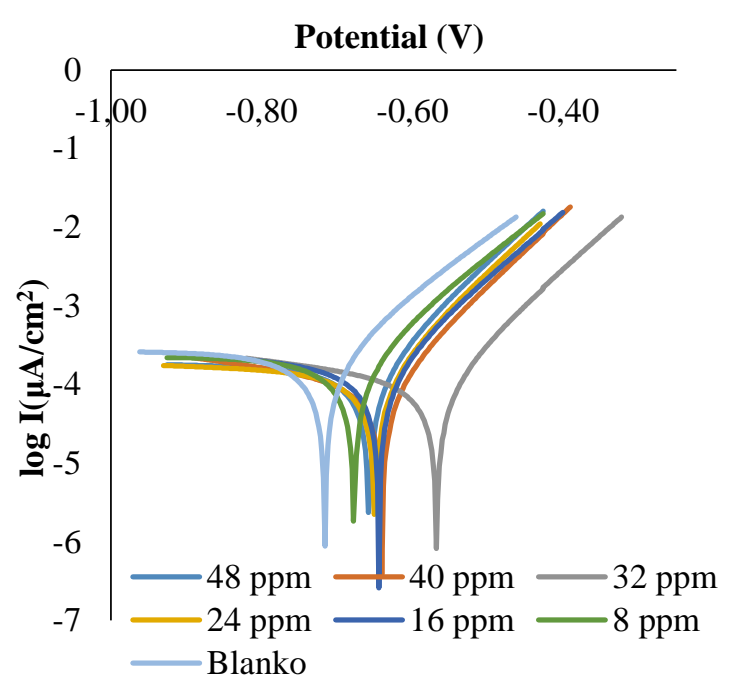

Gambar 3. Aluran Tafel sebelum dan sesudah penambahan ekstrak kulit buah manggis fraksi etil asetat dalam larutan elektrolit $\mathrm{NaCl} 1 \%$ jenuh karbon dioksida

Aluran Tafel dengan variasi konsentrasi inhibitor dapat memberikan gambaran tentang jenis inhibitor serta efektivitasnya. Pergeseran kurva untuk setiap peningkatan konsentrasi tidak menunjukkan perubahan yang signifikan dan tidak memiliki kecenderungan pergeseran yang tetap ke arah negatif atau positif sehingga senyawa fraksi etil asetat dapat dikategorikan sebagai inhibitor katodik dan anodik atau inhibitor campuran [1] [4]. Senyawa tersebut mampu menurunkan laju korosi, akan tetapi hanya terjadi sedikit perubahan dalam potensial korosi logam. Hal ini menunjukkan bahwa kedua senyawa menghambat reaksi anodik maupun reaksi katodik.

\section{Pengaruh Konsentrasi Inhibitor}

Hasil pengukuran laju korosi dengan metode ekstrapolasi Tafel pada variasi konsentrasi ekstrak kulit buah manggis fraksi etil asetat ditunjukkan pada Gambar 4.

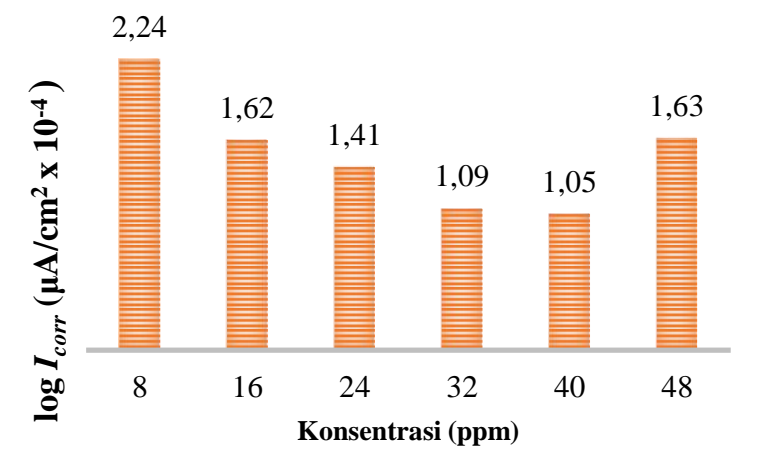

Gambar 4. Pengaruh konsentrasi senyawa ekstrak kulit buah manggis fraksi etil asetat terhadap laju korosi baja karbon pada suhu $25{ }^{\circ} \mathrm{C}$ dalam larutan $\mathrm{NaCl}$ $1 \%$ jenuh $\mathrm{CO}_{2}$
Terjadi penurunan laju korosi dari konsentrasi awal setelah penambahan inhibitor. Dengan bertambahnya konsentrasi inhibitor, terjadi penurunan laju korosi dan penurunan optimum terjadi pada konsentrasi inhibitor $40 \mathrm{ppm}$ dan laju korosi meningkat kembali pada saat konsentrasi inhibitor meningkat. Hal ini dikarenakan adsorpsi inhibitor pada baja karbon telah mencapai keadaan jenuh. Inhibitor tidak dapat lagi melindungi permukaan baja karbon, tetapi lebih tertarik pada media dan tersolvasi dalam media.

Setelah itu dapat terjadi desorpsi inhibitor kembali dari permukaan logam yang dapat meningkatkan laju korosi. Pada awal reaksi, peristiwa adsorpsi inhibitor pada permukaan logam lebih dominan dibandingkan dengan peristiwa desorpsi, sehingga adsorpsi berlangsung lebih cepat dan laju korosi menurun. Pada suatu waktu, laju adsorpsi sama dengan laju desorpsi disebut sebagai keadaan kesetimbangan. Setelah tercapai kesetimbangan, laju desorpsi bisa lebih cepat dari laju adsorpsi dikarenakan berbagai faktor (mekanik dan suhu) sehingga laju korosi meningkat.

\section{Pengaruh Konsentrasi Inhibitor terhadap Efisiensi Inhibisi}

Efisiensi inhibisi tertinggi ekstrak kulit manggis fraksi etil asetat adalah pada konsentrasi 40 ppm dengan efisiensi 60,37\%. Pada inhibitor korosi ekstrak kulit buah manggis fraksi etil asetat terdapat adanya tanin, alkaloid dan flavonoid hal ini dikuatkan dengan adanya uji fitokimia yang menunjukan hasil positif terhadap kedua zat yang memiliki gugus $\mathrm{O}-\mathrm{H}$ untuk mendonorkan sepasang elektronnya pada permukaan logam baja lunak ketika ion $\mathrm{Fe}^{2+}$ terdifusi kedalam larutan korosif sehingga memiliki kestabilan yang baik dibandingkan dengan tidak menggunakan inhibitor ekstrak kulit manggis fraksi etil asetat. Etil asetat merupakan pelarut semi polar yang mampu menarik senyawa aglikon maupun glikon dari kulit buah maggis, sehingga metabolit sekunder yang terkandung di dalamnya terlarut sempurna. 


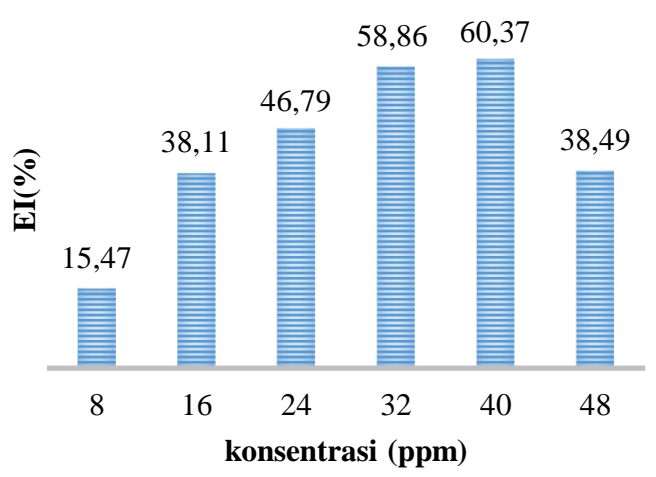

Gambar 5. Efisiensi inhibisi ekstrak kulit buah manggis fraksi etil asetat

\section{Pengaruh Suhu terhadap Efisiensi Inhibisi}

Variasi suhu juga dilakukan untuk mengetahui efisiensi optimum dari inhibitor ekstrak kulit buah manggis yang dipengaruhi oleh temperatur pada konsentrasi $40 \mathrm{ppm}$ dengan efisiensi terbesar pada pengujian variasi konsentrasi yakni sebesar $60,37 \%$. Hasil dari pengujian variasi suhu pada inhibitor ekstrak kulit buah manggis ditunjukkan pada Gambar 6.

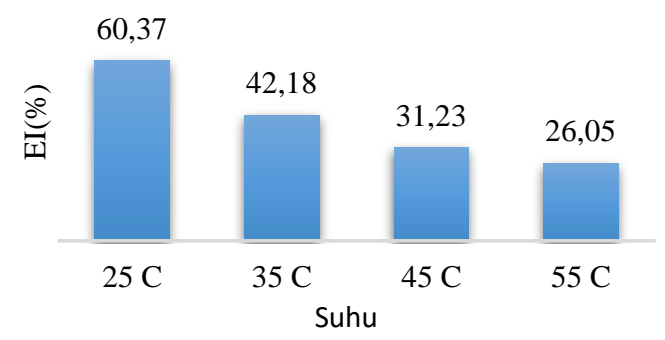

Gambar 6. Efisiensi inhibisi ekstrak kulit buah manggis fraksi etil asetat dengan variasi suhu

Pada Gambar tersebut terlihat adanya peningkatan pada nilai $I_{\text {corr }}$ yang mengakibatkan penurunan nilai efisiensi inhibisinya. Temperatur tinggi memberikan pengaruh ganda terhadap degradasi logam yang ditimbulkannya, kenaikan temperatur akan mempengaruhi aspek termodinamika dan kinetika reaksi, artinya degradasi akan semakin cepat pada temperatur yang lebih tinggi, kenaikan temperatur juga dapat mempengaruhi dan merubah struktur dan prilaku logam. Jika secara struktur berubah, maka secara umum kekuatan dan prilaku logam juga berubah. Jadi selain terjadi degradasi yang berupa kerusakan fisik pada permukaan atau kerusakan eksternal, juga terjadi degradasi penurunan sifat mekanik yang berakibat logam menjadi rapuh. Selain itu proses desorpsi inhibitor akan semakin cepat pada suhu tinggi, serta adanya kemungkinan inhibitor tersebut tidak tahan pada suhu tinggi.
Oleh karenan itu adanya peningkatan suhu mengurangi efisiensi inhibisi dan menimbulkan proses perkaratan semakin cepat. Dengan demikian suhu optimum inhibisi adalah pada suhu ruang.

\section{Isoterm Adsorpsi}

Isoterm adsorpsi dapat ditentukan jika pengaruh inhibitor disebabkan terutama karena adanya adsorpsi pada permukaan logam. Terdapat dua jenis adsorpsi suatu inhibitor organik pada permukaan logam yaitu secara fisik atau elektrostatik dan kemisorpsi [5]. Terdapat beberapa isoterm adsorpsi yang dapat digunakan untuk menjelaskan prilaku inhibitor dalam suatu medium. Berikut plot linier pada kurva isoterm adsorpsi Langmuir, seperti ditunjukkan pada Gambar 7 dengan $R_{2}=0,707$. Isoterm adsorpsi Langmuir membentuk lapisan monolayer pada permukaan baja dan terjadi adsorpsi elektrostatis.

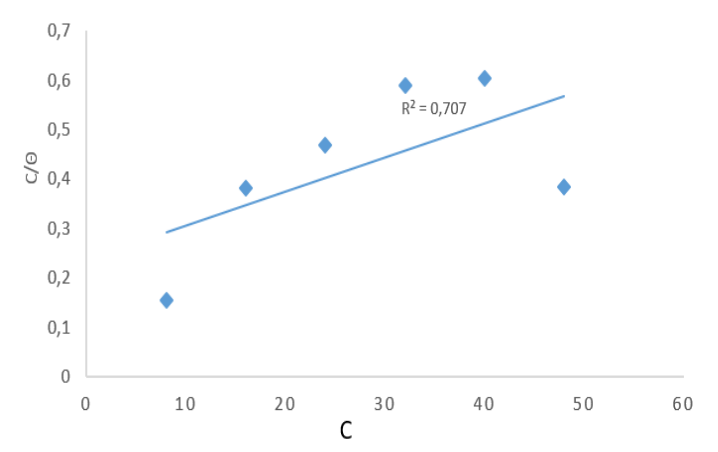

Gambar 7. Kurva Isoterm adsorpsi Langmuir

Sedangkan Gambar 8 menunjukkan plot linier pada kurva isoterm adsorpsi Temkim dengan $\mathrm{R}_{2}=0$,9847. Maka mekanisme adsorpsi ekstrak kulit buah manggis fraksi semi polar pada logam mengikuti isoterm adsorpsi Temkin sesuai Gambar 8 .



Gambar 8. Kurva Isoterm adsorpsi Temkin 
Isoterm Temkin menganggap adsorpsi pada semua molekul pada permukaan akan menurun linier dengan jumlah interaksi antara adsorbat dan adsorben. Entalpi adsorpsi sering menjadi kurang negatif saat $\theta$ bertambah, hal ini menunjukkan dari segi energinya, akan ditempati lebih dahulu [6].

\section{SIMPULAN}

Dari hasil penelitian ini dapat ditarik kesimpulan bahwa pada ekstrak kulit buah manggis terdapat metabolit sekunder berupa alkaloid, tanin dan flavonoid yang berpotensi menjadi inhibitor korosi. Peningkatan konsentrasi ekstrak kulit buah manggis dapat meningkatkan efisiensi inhibisi. Konsentrasi optimum yang diperoleh yakni $40 \mathrm{ppm}$ dengan efisiensi sebesar $60,37 \%$. Adanya peningkatan suhu menurunkan efisiensi inhibisi, sehingga inhibitor optimal menghambat laju korosi pada suhu $25^{\circ} \mathrm{C}$.

\section{UCAPAN TERIMA KASIH}

Terimakasih kepada Kepala laboratorium Kimia Fisik Material Institut Teknologi Bandung dan seluruh pihak yang berkontribusi pada penelitian ini.

\section{REFERENSI}

[1] B Bundjali, Tinjauan Termodinamika dan Kinetika Korosi serta Teknik-Teknik Pengukuran Laju Korosi. Bandung: ITB, 2000.

[2] K R Trethewey and J Chamberlain, Korosi untuk Mahasiswa Sains dan Rekayasa.: Gramedia Pustaka Utama, 1991.

[3] Tety Sudiarti, "Korosi Baja Karbon dalam Lingkungan Air Sadah," ITB, Kota Bandung, Tesis 2008.

[4] B Bundjali, "Perilaku dan Inhibisi Korosi Baja Karbon dalam Larutan Buffer Asetat, Bikarbonat-CO2," ITB, Bandung, Disertasi 2005.

[5] V S Sastri, Corrosion Inhibitor: principles and Aplication. New York: John Wiley \& Sons Ltd, 1998.

[6] P W Atkins, Kimia Fisika Jilid 2.: Erlangga, 1996. 